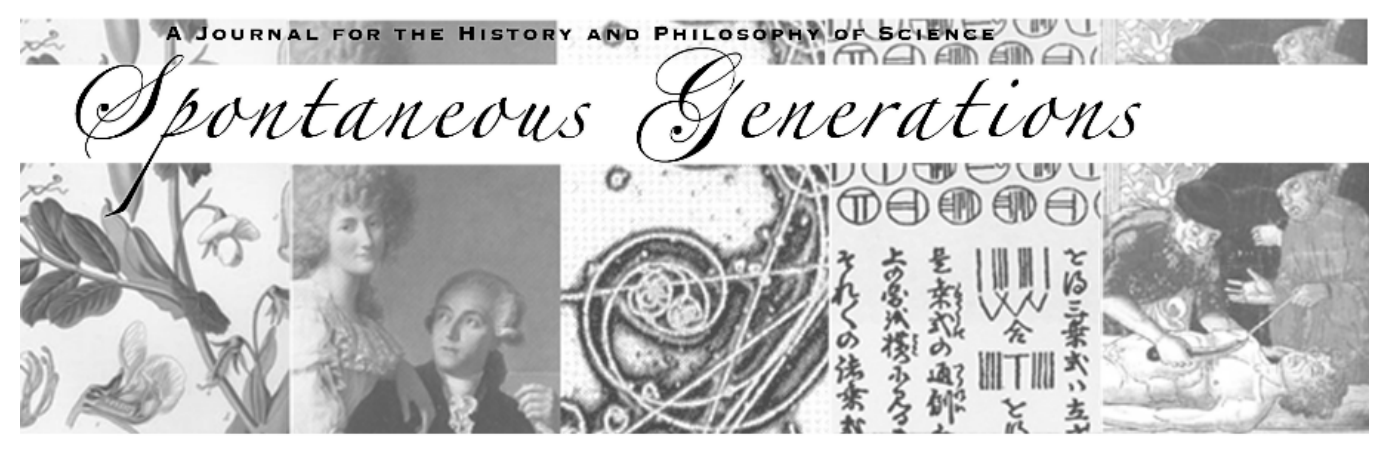

\title{
Public University Funding and the Privatization of Politics
}

Author(s): Mark B. Brown

Source: Spontaneous Generations: A Journal for the History and Philosophy of Science, Vol. 7, No. 1 (2013) 21-28.

Published by: The University of Toronto

DOI: 10.4245/sponge.v7i1.20002

\section{EDITORIAL OFFICES}

Institute for the History and Philosophy of Science and Technology

Room 316 Victoria College, 91 Charles Street West

Toronto, Ontario, Canada M5S 1K7

hapsat.society@utoronto.ca

Published online at jps.library.utoronto.ca/index.php/SpontaneousGenerations ISSN 19130465

Founded in 2006, Spontaneous Generations is an online academic journal published by graduate students at the Institute for the History and Philosophy of Science and Technology, University of Toronto. There is no subscription or membership fee. Spontaneous Generations provides immediate open access to its content on the principle that making research freely available to the public supports a greater global exchange of knowledge. 


\title{
Public University Funding and the Privatization of Politics*
}

\author{
Mark B. Brown ${ }^{\dagger}$ \\ This essay first examines a few key aspects of the erosion of public \\ university funding in the United States, showing how the ideal of \\ value-free science has undermined efforts to defend a conception \\ of universities as public goods. Then it considers how advocates of \\ California's Proposition 30, a ballot initiative that restored some public \\ university funding, frequently adopted the same logic of privatization \\ they sought to counteract.
}

The battle for the soul of the public research university is now being fought with ice cream. In fall 2012 the University of California's Office of the President tried to drum up public support for higher education by sending a gelato truck to tour the state. The truck distributed gelato bars at each of the UC system's ten campuses, the wrappers decorated with "fun facts" about the University's social and economic impact: "Did you know that a UC San Diego alumnus was the first to sequence the human genome? Or that Vitamin $\mathrm{K}$ was discovered at UC Berkeley?" (Luciani 2012). According to a UC spokesperson, "[w]e hope that building understanding of how UC contributes to the daily lives of all Californians will further strengthen public appreciation and support for the mission of public higher education in our state" (Daily Bruin 2012). The gelato truck was part of an outreach effort called Onward California, created in response to decades of cuts in public funding. It included a nearly $\$ 3$ million advertising campaign, with a large banner at the Oakland airport and flashy video spots featuring upbeat music and happy students. Such publicity campaigns have become common among public universities in the United States. And rather than seeking to restore public funding, they tend to emphasize the need for private support. According to UC's director of marketing and communications, "[r]egardless of what happens with state funding, we're going to continue to need to grow private and corporate philanthropy, so the campaign is done to raise consciousness of [that]" (Daily Bruin 2012).

* Received 20 August 2013.

$\dagger$ Mark B. Brown is Professor in the Department of Government at California State University, Sacramento. He is the author of Science in Democracy: Expertise, Institutions, and Representation (MIT Press, 2009), and various other publications on the politics of expertise, citizen participation, bioethics, climate change, and related topics. 
Such campaigns for private funding are part of a trend toward conceiving university research primarily in terms of its economic value (Radder 2010). Many studies have considered how the increasing emphasis on commercially viable research creates a potential for both coercive pressure and moral corruption (Brown 2010). But the privatization of university science affects more than just the practice, culture, or products of science itself. It also has implications for the potential of academic research to foster social justice and democratic politics.

The recent commercialization and privatization of university science should not be understood as a departure from a previous golden age of pure science. Someone has always had to pay the bills, and universities have long been intertwined with economic ideas and interests. Nonetheless, during the past forty years or so, there has been an increasing tendency to conceive of academic institutions in primarily economic terms. Until about the mid-twentieth century, in contrast, many university leaders saw the university's intellectual and economic dimensions as contributions to its civic dimension (Lustig 2005, 23-24). As Andrew Jewett (2012) argues, between the 1860s and the 1960s a large and diverse group of American thinkers "contended that science, as they understood it, offered the basis for a cohesive and fulfilling modern culture" (Jewett 2012, 9). During the late nineteenth century, university leaders at Cornell, Harvard, and Johns Hopkins maintained that academic science embodied republican values opposed to both doctrinaire religious colleges and Gilded Age commercialism. During the 1920s and 30s, scholars in the "cultural sciences"-John Dewey, Franz Boas, Edward A. Ross, George Herbert Mead, and others-developed a constructivist, contextual view of science as inevitably shaped by social values. Some emphasized the civic virtues they associated with science: humility, reasonableness, respect for evidence, and orientation toward the public good. Others argued that science was required for making effective public policy. But they agreed that university science both required and promoted social engagement and public deliberation.

These "scientific democrats"-as Jewett calls them-faced opposition from two kinds of critics that remain prevalent today. First, humanists like Irving Babbitt, Reinhold Niebuhr, and Lewis Mumford accused the scientific democrats of amoral materialism and scientism. These humanists joined conservatives in arguing that society requires fixed moral foundations, which universities should promote through study of the "great books." Second, physical scientists argued that the scientific democrats, and the cultural sciences in general, were incapable of producing objective knowledge. They saw the cultural sciences as misguided efforts to apply the scientific method to society. Most importantly, although these physical scientists and humanists disagreed on whether science was good or bad for society, they implicitly agreed on a view of science as socially detached and value-free (Jewett 2012, 229-231). By the 1950s, a division of labor had emerged between the natural sciences and humanities, with most 
social scientists choosing sides (310). People still saw higher education as providing social benefits, but most associated the benefits with physical sciences and engineering, rather than social and cultural sciences; they emphasized military, medical, and consumer technologies, rather than civic values, political knowledge, or personal development; and they assumed that genuine science had to be value-free and protected from public concerns, rather than produced through intelligent interaction with the general public (Guston 2000, 37-63).

Nonetheless, the rapid expansion of public universities after World War II contributed to the general education of ordinary citizens, which was a key factor in the postwar growth of the American middle class (Newfield 2008). But the American public's commitment to higher education soon faced multiple challenges. The culture wars of the 1960s and beyond raised concerns that public funds were being wasted on rebellious students and self-indulgent faculty. The budget crises of the 1970s, followed by the rise of anti-government ideologies in the 1980s, led to massive cuts in public funding for higher education. In 1987 public colleges and universities received over three times as much revenue from state and local governments as from students; today they receive about the same from each. Meanwhile, median household income has increased by only about 3 percent since 1991, while tuition at four-year public universities has increased by 58 percent, adjusting for both inflation and increased grants and tax breaks. Since 2008, average state spending per full-time student at US public universities has declined by 28 percent after adjusting for inflation (Oliff et al. 2013).

Universities have responded to cuts in state funding with a massive reshaping of their employment structures. In 1969 tenured and tenure-track positions made up over 75 percent of the faculty, and non-tenure-track positions accounted for about 20 percent. By 2009 the situation had reversed: tenured and tenure-track faculty had declined to 33.5 percent of the faculty, and 66.5 percent were on contingent appointments and ineligible for tenure (Kezar and Maxey 2013). ${ }^{1}$ Treated like second-class citizens and vulnerable to both the job market and capricious administrators, contingent faculty lack the basic preconditions of professional autonomy. Nonetheless, contingent faculty have become essential to the economic survival of American universities. Teaching far more yet paid far less than tenured and tenure-track faculty, contingent faculty effectively subsidize the rest of the university, including scientific research.

It is widely assumed, of course, that the reverse is the case, and that the natural sciences and engineering subsidize other departments. Science and engineering faculty acquire huge extramural grants from the federal government and private funders, while the social sciences and humanities rely on state taxes

1 The average percentage of faculty with contingent appointments varies among different types of institutions: at public two-year colleges (community colleges) it's over eighty percent, at private research universities about 65 percent, and at public research universities about 50 percent (Kezar and Maxey 2013). 
and student fees. But what many faculty don't know is that extramural grants generally cover only part of the "indirect costs" of overhead (administration, staff, facilities, etc.), and host universities have to pay the rest. According to one calculation (Newfield 2008, 212; Newfield 2010), if a university receives $\$ 200$ million in outside grants, it will need to spend between $\$ 7$ million and $\$ 33$ million of its own money to fully cover the indirect costs. Meanwhile, universities receive public funding and/or student tuition in proportion to the number of students enrolled. The humanities and social sciences generally teach more students than the natural sciences and engineering, so administrators transfer money from the former to the latter. Such cross-campus subsidies are effectively concealed by the mid-twentieth-century division of labor mentioned previously. The humanities and humanistic social sciences are not seen as producing socially useful knowledge, so in good economic times they may be kindly supported by the "real" producers of epistemic and economic progress, and in bad times sent to the chopping block (Newfield 2008, 208-219).

American universities have also responded to the decline in public funding by cutting faculty positions, course offerings, and library services, among other things. And they have increased tuition by an average of 27 percent since 2008, after adjusting for inflation. Seven states have increased tuition by more than 50 percent, and Arizona and California have increased tuition by over 70 percent. $^{2}$ Meanwhile, during the same time period, student enrollment has increased by about 12 percent, while the number of full-time equivalent instructors has increased by only about 6 percent. And in five states, including California, the number of full-time instructors has actually decreased while enrollment has increased (Oliff et al. 2013). University education is being redefined as a private good paid for by individual "user fees," which puts it out of reach for increasing numbers of qualified students from lower socioeconomic groups.

The Onward California initiative mentioned in the introduction was symptomatic of this overall trend toward privatization. Ironically, it was also part of a broader effort by university officials during the summer and fall of 2012 to promote Proposition 30, a public education ballot initiative submitted to the California electorate for direct vote. In a rare victory for public funding, the initiative was approved in November 2012 by a margin of 55 percent to 45 percent. It raised the state personal income tax on wealthy residents from 9.3 percent to as much as 12.3 percent for seven years, and it raised the state sales tax by 0.25 percent for four years. It promised to generate about $\$ 6$ billion annually, temporarily preventing further cuts to both $\mathrm{K}-12$ schools and higher education.

2 Some but not all of these increases have been offset by increased federal financial aid and tax subsidies. At institutions that award graduate degrees, increased federal funding has offset about 60 percent of state cuts, but federal funding has offset only 30 percent of state cuts for institutions that award only bachelor's degrees, and it has offset only 14 percent of state cuts for community colleges (Oliff et al. 2013). 
Prior to the November vote, opponents said the revenue would be diverted to non-educational purposes, and that the initiative failed to address waste and administrative bloat. They also accused Prop. 30 advocates of politicizing university classrooms, thus violating the ideal of value-free science.

The stage was set in June, when the state government adopted a fiscal 2012-13 budget that contained $\$ 6$ billion in "trigger" cuts, mostly to education, if voters were to reject Prop. 30. In a similar move, the Board of Trustees of California State University (CSU) approved a 5 percent tuition increase if Prop. 30 were defeated, as well as a $\$ 250$ tuition refund if it were to pass. The CSU administration also sent a letter to parents of prospective students, warning that their child might not be admitted if the initiative were defeated. According to one report, "CSU officials deny any political motivations behind the letter and say they are just trying to level with students about realities of the CSU system" (Ravindhran and Garcia 2012). Not surprisingly, opponents of Prop. 30 perceived these measures as politically motivated efforts to blackmail California voters.

Critics of Prop. 30 also objected to overt political engagement by university faculty and administrators. It did not cause much complaint when the UC Board of Regents and the CSU Board of Trustees endorsed Proposition 30, but critics cried foul when faculty discussed Prop. 30 in their classes. The CSU Chancellor's office responded by asking administrators on all CSU campuses to remind faculty to avoid "inappropriate political advocacy" (Cocca 2012). On my campus, CSU Sacramento, faculty received an email from the Provost informing us that "under Cal. Gov. Code Section 8314, it is unlawful for any state employee to use, or permit others to use, state resources for a campaign activity. This includes making presentations about Proposition 30 unless a discussion of Proposition 30 is relevant to the regular course material." Concerns about classroom advocacy were not entirely unfounded. Many faculty felt strongly about the initiative, and the CSU faculty union had distributed less-than-neutral PowerPoint slides and talking points for faculty to "inform" their students about Prop. 30. The Howard Jarvis Taxpayers Association, a prominent anti-tax group, filed a lawsuit against CSU Monterey Bay alleging that a professor had sent students an email urging them to support Prop. 30 (Puente 2012). Faculty should never pressure students to adopt a particular political view, and to the extent that some faculty may have done so, their critics had a point.

But as often happens in such cases, the administrative response amounted to overkill. The California Code cited by my Provost does not actually ban faculty from using state resources for "making presentations about Proposition 30 ," but only presentations in favor of such initiatives. Nor does it require that such presentations be "relevant to the regular course material." To be sure, faculty should generally stick to the announced course topic, but faculty themselves are the best judges of what belongs to a particular topic, and many faculty promote student interest by linking course material to current events. 
Faculty in the natural sciences and engineering, for example, might use a short discussion of an issue like Prop. 30 to address the way public funding shapes research in their fields. Moreover, the state code expressly allows "a fair and impartial presentation of relevant facts to aid the electorate in reaching an informed judgment regarding the bond issue or ballot measure." Rather than encouraging faculty to promote such informed judgment, the administration preemptively capitulated to conservative efforts to insulate the university from society and politics, under the guise of protecting scientific objectivity and academic freedom.

This capitulation echoed a fifty-year history of conservative attacks on those who see promoting a more inclusive and educated society as a key part of the public university's mission. The 1964 Free Speech Movement at UC Berkeley began in response to the administration's attempt to prevent student political organizations from meeting on campus. Throughout the 1960s, student activists faced criticism not only for their political views, but also for their vision of the university as a site of political discussion and debate. During the 1970s and 80s, when feminists and multiculturalists started programs in Women's Studies and Ethic Studies, and when they called for a more inclusive canon of "great books," critics accused them of politicizing higher education. During the 1990s, when students called for an end to language that denigrates members of disadvantaged groups, critics obsessively quoted a few heavy-handed speech codes and demonized the entire project as a violation of free speech and the imposition of "political correctness" (Newfield 208, 51-67).

In the controversy over Prop. 30, many faculty, apparently unconcerned about this history, accepted arguments like that of my Provost and refrained from discussing the issue in their classes. The UCLA campus newspaper concluded, "[i]t seems, then, that standing up for Proposition 30 falls to private individuals" (Daily Bruin 2012). This assessment was doubly correct, because the private individuals advocating Prop. 30 tended to speak in distinctly private terms. Many faculty and administrators worked long hours on their own time to promote Prop. 30, but they often focused on the narrow economic benefits of the measure, rather than, say, the contribution of public universities to scientific discovery, social criticism, or personal development. When the leaders of California's public colleges and universities attended a morning rally on the steps of the State Capitol on May 1, 2012, they emphasized one key point: "[e]nergize the state's economy by reinvesting in higher education." Like many others, they reported that "for every $\$ 1$ the state invests in higher education, it gets a return of $\$ 4.50$ " (Hemmila 2012). By defending Prop. 30 on primarily economic grounds, its defenders reinforced the same tendency to privatize public goods that made the initiative necessary in the first place.

Unfortunately, even the most publicly minded university administrators face a Catch-22 when responding to cuts in public funding and other forms of 
privatization. To attract private funding and justify increasing student fees, they need to maintain their reputation for quality. So they praise the university's adaptability, inventiveness, and entrepreneurial spirit. But if they suggest the university can do more with less, they hurt their case for public funding. "Taxpayers then reasonably ask, if the university does not need more money, why does it keep raising fees? And since it keeps raising fees, why should we give it more money?" (Newfield 2008: 182). A similar Catch-22 arises for faculty who become politically engaged. If they criticize privatization, or merely raise the topic for class discussion, critics accuse them of violating academic neutrality and indoctrinating their students. But if they remain silent, they fail to address the policies that threaten their profession. Academic neutrality thus easily becomes a cloak for political passivity (Lustig 2005, 29, 43).

A more effective approach depends on challenging not only the decline in public university funding, but also the ideal of value-free science. That widely criticized but persistent conception of science underlies the ongoing division of labor between the natural sciences and humanities, and tends to isolate both from social and political concerns. Without the ideal of value-free science, it becomes easier to see that, unlike gelato bars, academic freedom and professional autonomy are not private goods. They are best protected not by social insulation but by intelligent social engagement. Put differently, those concerned about the privatization of academic science should be equally concerned about the privatization of university politics.

MARK B. Brown

Department of Government

California State University, Sacramento

6000 J Street, Sacramento, CA 95819-6089 USA

mark.brown@csus.edu

\section{RefERENCES}

Brown, Mark B. 2010. Coercion, Corruption, and Politics in the Commodification of Academic Science. In The Commodification of Academic Research: Science and the Modern University, eds. Hans Radder, 259-276. Pittsburgh, PA: University of Pittsburgh Press.

Cocca, Christina. 2012. CSU Faculty Receive Email Urging Discretion on Political Talk. Daily Sundial (Northridge, California). October 21. http://sundial.csun.edu/2012/10/csu-faculty-receive-email-urging-discretion-onpolitical-talk/

Daily Bruin. 2012. Editorial: UC Needs Outside Support for Prop 30. October 12. http://dailybruin.com/2012/10/17/_editorial-uc-needs-outside-support-for-prop30 
Hemmila, Donna. 2012. Higher Ed Chiefs Join Forces for State Budget Advocacy. Press Release, UC Newsroom. http://www.universityofcalifornia.edu/news/article/ 27613

Jewett, Andrew 2012. Science, Democracy, and the American University: From the Civil War to the Cold War. Cambridge: Cambridge University Press.

Kezar, Adrianna, and Daniel Maxey. 2013. The Changing Academic Workforce. Trusteeship. 3:21 (May/June). http://agb.org/trusteeship/2013/5/changingacademic-workforce

Guston, David. 2000. Between Politics and Science: Assuring the Integrity and Productivity of Research. New York: Cambridge University Press.

Luciani, Kristin. 2012. Onward California Tour to Stop at UC San Diego. University Communications and Public Affairs, UC San Diego. http://ucsdnews.ucsd.edu/feature/onward_california_tour_to_stop_at_uc_san_ diego

Lustig, Jeff. 2005. The University Revisioned: The Alternative to Corporate Mis-education. The Review of Education, Pedagogy, and Cultural Studies 27: $17-52$.

Newfield, Christopher. 2008. Unmaking the Public University: The Forty-Year Assault on the Middle Class. Cambridge, MA: Harvard University Press.

Newfield, Christopher. 2010. Avoiding the Coming Higher Ed Wars. Academe. American Association of University Professors. http://www.aaup.org/article/avoiding-coming-higher-ed-wars\#.UhAKbG3N6Sp

Oliff, Phil, Vincent Palacios, Ingrid Johnson, and Michael Leachman. 2013. Recent Deep State Higher Education Cuts May Harm Students and the Economy for Years to Come. Center on Budget and Policy Priorities. March 19. http://www.cbpp.org/cms/?fa=view\&id=3927\#_ftn7

Puente, Kelly. 2012. Prop 30 Advocates Use Scare Tactics That May Be Illegal, Says Taxpayers Association. San Bernardino County Sun. October 28. http://www.huffingtonpost.com/2012/10/27/prop-30-advocates_n_2029142.html

Radder, Hans, ed. 2010. The Commodification of Academic Research: Science and the Modern University. Pittsburgh, PA: University of Pittsburgh Press.

Ravindhran, Subha, and Sid Garcia. 2012. CSU Committee Approves Contingency Plan for Proposition 30. KABC-TV Los Angeles, CA. September 18. http://abclocal.go.com/kabc/story?section=news/state\&id=8814866 